\title{
Public Health Disasters and the Evolution of Pandemic Response Structures: A Case Study of MERS in Korea*
}

\author{
Jiyoun Chang**
}

\begin{abstract}
This study focuses on the Korean MERS epidemic and analyzes how governance structures were set up to respond to it. Compared to other countries' responses, which were built on both hierarchical and network structures, the Korean MERS response structure evolved over time. In the first period hierarchy characterized the relationship between the central government and hospitals. In the second period, heterarchy replaced hierarchy, and in the last period heterarchy evolved into a network governance structure. Furthermore, it was found that leadership, communication, information sharing and use of information technology affected the formation of the response structures. I conclude by exploring limitations in my research and suggesting paths and perspectives for further research.
\end{abstract}

Keywords: public health disasters, governance structure, infectious disease, epidemic/pandemic response, MERS, Korea

\section{INTRODUCTION}

Over the past few years, a number of people throughout the world have become infected with and have died from emerging infectious diseases, despite the great advances modern medical science has made. Nathan Wolfe, a celebrated virologist, has called it a "viral storm" in a new pandemic age (2011). In the wake of these pandemics, many researchers and practitioners have searched for an effective way to tackle these public health disasters.

Western countries, such as those in Europe, the United States, and Canada, have well-established public health prevention and response systems. However, unlike these

\footnotetext{
* An earlier version of this paper was presented at 2016 Annual Meeting of the Korean Association for Public Administration (KAPA) in Osong, South Korea, on June 24, 2016.

** Jiyoun Chang is a PhD candidate at Ewha Womans University, Seoul, Korea. E-mail: jiyoun.chang72@gmail.com.
}

Manuscript received October 25, 2016; out for review November 1, 2016; review completed March 6, 2017; accepted March 8, 2017.

The Korean Journal of Policy Studies, Vol. 32, No. 1 (2017), pp. 27-52.

(C) 2017 by the GSPA, Seoul National University 
countries, Korea has paid relatively little attention to public health policy and to pandemic response systems, and so these systems are still, unfortunately, in the early stages of development (K. S. Lee, 2015). In May 2015, due to the MERS outbreak, 186 people were infected and 38 died in Korea - the most second highest death toll after that of Middle East countries.

Such a transboundary crisis needs to be effectively managed. Disaster and crisis management has become not only a governmental concern but a social one. This makes it a "wicked problem" (Rittel \& Weber, 1973) which is difficult to solve or deal with due to incomplete and confusing information, conflicting interests, and changing demands (Churchman, 1967; Koppenjan \& Klijn, 2004). Collaborative governance or network governance is considered to be a solution to this problem in public administration in the modern era, and it has recently attracted the attention of scholars and practitioners in disaster and crisis management studies.

My research questions have emerged from inquiries into what governance structures tend to prevail in public health emergency situations - a hierarchical, network, or other type of structure - and what circumstances might account for the development of these structures.

This paper is organized as follows. The first part examines the literature related to public health disasters, governance structures, and the formation of such structures. The second part explains the case research method I have adopted and the third part analyzes the case. Finally, the last section addresses the implications of my research for future work and practice.

\section{THEORETICAL BACKGROUND}

\section{Public Health as a Disaster}

A disaster is "any occurrence that causes damage, ecological disruption, loss of human life, or the deterioration of health and health services on a scale sufficient to warrant an extraordinary response from outside the affected community area" (Noji, 1996; World Health Organization, 2015). Public health emergencies are considered disasters. There are innumerable types of crises and disasters; they are generally classified as either natural or manmade/technological (Dynes, 1970; Baum, Fleming, \& Davidson, 1983; Hodgkinson \& Stewart, 1991; Quarantelli, 1993). Infectious diseases are categorized as the latter. Their outbreak is sudden, unpredictable and, to some extent, controllable.

Moreover, because the epicenter of a pandemic is cross-societal and because it 
tends to spread fast across regions and borders (Drennan, McConnell, \& Stark, 2014, pp. 19-27), pandemics are categorized as transboundary crises (Ansell, Boin, \& Keller, 2010), the response to which is complex. Infectious disease knows no geographic boundaries and can become an epidemic, and when it spreads globally the epidemic becomes a pandemic (Landesman, 2012, p. 324). Infectious disease is also in a subcategory of social disaster under the Infectious Disease Control and Prevention Act in Korea, which includes various viral diseases (for example, H1N1, SARS, MERS, etc.)

\section{Governance Structure and the Response to Public Health Disasters}

Governance structures have generally been discussed in terms of three concepts: hierarchy, network, and market (Rhodes, 2000; Powell, 2003). Stephenson (2009 \& 2014) elaborates on these types governance structures. ${ }^{1}$

Recent studies have made an effort to research structures that mix hierarchy and networks (Denis, Ferlie, and Van Gestel, 2015; Bardach; 2015; Hermansson; 2016; Skelcher, 2012; Skelcher \& Smith, 2015; Ferlie, McGivern, and Bennett, 2013). Mars (2013), following Stephenson (2009), analyzes pandemic threats in terms of hierarchical, heterarchical, and networked governance structures. He asserts that heterarchy is an adequate interorganizational approach to a pandemic threat. Provan and Kenis's (2008) typology of network governance in public service, which features a self-governance network, a network administrative organization network, and a lead organization network offers insights into a mixed network governance structure. ${ }^{2}$ A lead organization

1. Types of governance structure range from hierarchy to heterarchy, network, and market. However, I exclude market here because the governance structures in this study are focused on the public sector: the market is not relevant to disaster and crisis management, especially in public health disaster management.

2. In self-governed networks, all participants have equal power, so no authority is centralized in the network. Network administrative organizations (NAO) with more power than selforganizational networks play a management role but do not participate in the network (Kenis \& Provan, 2009).

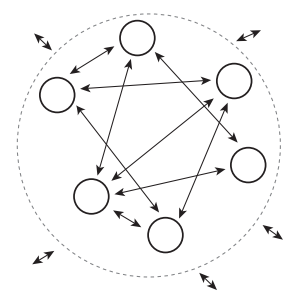

Shared governance network

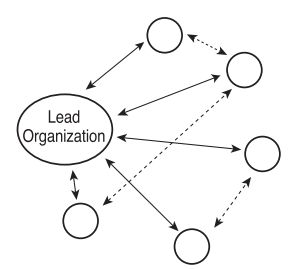

Network administrative organization network

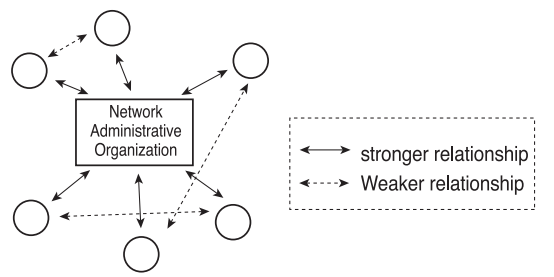

Lead organization network 
network is the most hierarchy oriented among the three forms of network. The lead organization in this model has more power and authority than the other participants in the network and stronger relationships with them than they have with each other.

Moynihan (2008a) researched a hybrid incident command system, which successfully managed an epidemic of exotic Newcastle disease. The Centers for Disease Control and Prevention likewise used this system when it assumed the role of lead organization in the U.S. national response to the 2009 H1N1 epidemic (Ansell \& Keller, 2014, p.8).

Disaster management experts argue that public health disasters need to be managed in a cycle of four steps: prevention, preparedness, response, and recovery (Petak, 1985; McLoughlin, 1985; Waugh, 1994; Drennan, McConnell, \& Stark, 2014, pp. 30-31). Among these processes, the disaster response step is paramount for infectious diseases. When there is no vaccine or medical treatment available, this step is even more crucial (World Health Organization, 2015). ${ }^{3}$

Due to the characteristics of such diseases, we can infer that the governance structure instituted for prevention and response will differ from that put in place to cope with other types of disasters. Several researchers have argued that a centralized approach needs to be taken to respond to infectious diseases rather than the network management approach that is used in responding to natural disasters (Nolte \& Boenigk, 2011; Kapucu, Arslan, \& Collins, 2010; Schwartz, 2012; Mars, 2013, Ansell \& Keller, 2014). At the same time, however, because infectious disease is such a knowledge-based crisis (Ansell \& Keller, 2014), a network approach that allows for the collaboration of other professions and other sectors is critical. It can be an emergency if sufficient technical or professional personnel, organizational experience and necessary equipment is not available (Landesman, 2012). Thus, we can infer that an appropriate response structure for a pandemic would be a combination of a hierarchical and network approach. This is why this study focuses on the government's role in the response step.

\section{Evolution of Pandemic Response in Korea}

According to the socio-ecological perspective, governance structure evolves from hierarchy to heterarchy to network (Cumming, 2016). This concept of evolution in

3. In December 2015, the World Health Organization reported eight new infectious diseases for which no vaccine is available: Crimean Congo, Ebola, Marburg, and Lass hemorrhagic fever, MERS and SARS coronavirus diseases, and Nipah and Rift Valley fever (WHO, 2015). 
pandemic response needs to be reexamined in the context of Korea because the current Korean public administration system that deals with social disasters is hierarchical.

Both hierarchical and network structures have played roles in response to pandemics around the world. In these cases, the government initiated the response but diverse organizations also participated in the network.

The UK's Public Health England is a good example of a networked response to infectious disease in that its outbreak control team includes an epidemiologist, microbiologist, communicator, public officials, and a specialist in environment health that rapidly communicates with the public. During the 2002-3 outbreak of SARS, Tawain's Department of Health and its disease control center established a media network that worked with the local department of health and local medical centers to ensure that medical teams and institutions were able to communicate with the public. Government-designated hospitals shared information with the public by uploading it onto their websites, and a public-private partnership resulted in the establishment of community disease control centers in every borough. The Singapore government actively communicated with the community, foreign companies, diplomats, and diverse religious and trade organizations via an official communication channel, the Singapore network, right after the outbreak began.

In contrast, in Korea the strongly hierarchical public administration arm of the government holds a lot of power. Studies about the balance of forces in disaster management suggest that the public administration segment takes on more responsibility for disaster management in Korea (Alexander, 2007; Kim, Chung, \& Ahn, 2009; Lee, Choi, \& Chung, 2014) than do public administration agencies in other countries (see Alexander, 2007, p. 54).

The Korean government has not paid much attention to managing disasters, especially under President Park. The traditional hierarchical nature of government regimes in Korean means that the governance structure established at the outset of a disaster is likewise hierarchical. Over the course of the evolution of managing a disaster, networks do emerge, even in Korea, and so the governance structure is likely to ultimately present as a mixed one in which a hierarchical structure is embedded. Because the hierarchical structure forms the bedrock, the government's centralized decision making is evident even in networks. ${ }^{4}$

4. Similarly, Hermansson (2015) found in his research on disaster management collaboration in Turkey that, unlike in Western Europe, both hierarchy and bureaucracy were embedded in the network structure. 


\section{Factors Influencing Response Structures}

\section{Leadership}

Leadership is not only important in disaster response but plays a critical role in the formation of disaster response structures (Bryson et al., 2006). Analyzing George. W Bush's leadership style in the wake of Hurricane Katrina, Preston (2008) demonstrates how crucial a leader is in shaping the response to a crisis. Additionally, facilitative leadership contributes to the development of collaborative governance (Ansell $\&$ Gash, 2008), and an imbalance of power in leadership undermines the effectiveness of disaster management collaboration (Hardy and Philip, 1998). Drennan, McConnell, and Stark (2014) posit leadership as a key to shaping the outcomes of disaster response.

\section{Communicati on and Information sharing}

Crisis communication in general pertains to public health, safety, conflict resolution and emergency response (Lundgren \& McMakin, 2013). ${ }^{5}$ Communication plays a pivotal role in the success of disaster response (Agranoff \& McGuire, 1998; Kapucu, 2006; Levinson \& Granot, 2002).

Information sharing in disasters can also influence the change of governance structures, and it operates differently in each of the structures. Information sharing in a hierarchical structure is likely to be constrained due to the narrow flow of information in it compared to in a heterarchy, which provides more opportunities for actors to interact and share ideas, meaning it tolerates information exchange much better (Forrer, Key, \& Boyer, 2014). During the SARS outbreak, for example, the Singapore government's sharing of information through the newly designed flat task force eliminated delays caused by bureaucratic structures (Leidner, Pan, \& Pan, 2009; Bailetti, Callahan, \& DiPietro, 1994).

5. Crisis communication has focused on organizations' or agencies' strategic responses to crisis after an event (Benoit, 1995; Coombs, 1995; Seeger, Reynolds \& Sellnow, 2008; Walaski, 2011), while risk communication has what affects behavior before an event, such as how persuasive communicators are and their personal perception of risk (Covello, 1992; Seeger et al., 2008; Walaski, 2011). However, efforts have been made to combine the two notions, and the Centers for Disease Control and Prevention has now integrated them as crisis and emergency risk communication (Reynolds \& Seeger, 2005). 


\section{Use of Information Technology}

Landesman (2012) explains that information technology (IT) is necessary in public health disaster management. Using IT results in better communication and information sharing during disasters, because when IT infrastructures are set up information becomes much more readily accessible. Using devices such as smartphones and social media such as Facebook or Twitter likewise leads to more effective gathering and distribution of information and makes the governance structure more flat.

\section{GOVERNANCE STRUCTURE DURING THE MERS OUTBREAK IN KOREA}

In disaster situations, governance structures are influenced by diverse factors. Here, I focus on analyzing how the structures formed and evolved in case of the MERS outbreak in Korea. Based on the assumption that in Korea, governance structures during disasters are likely to evolve from hierarchical to network based, I draw on Stephenson's (2009) concepts of hierarchy and heterarchy. In addition, I have adopted Kenis and Provan's (2009) concept of network governance, as it provides a better way to understand Korean network structures than does Stephenson's. The research analytic framework is shown in figure 1.

Figure 1. Analytic Framework

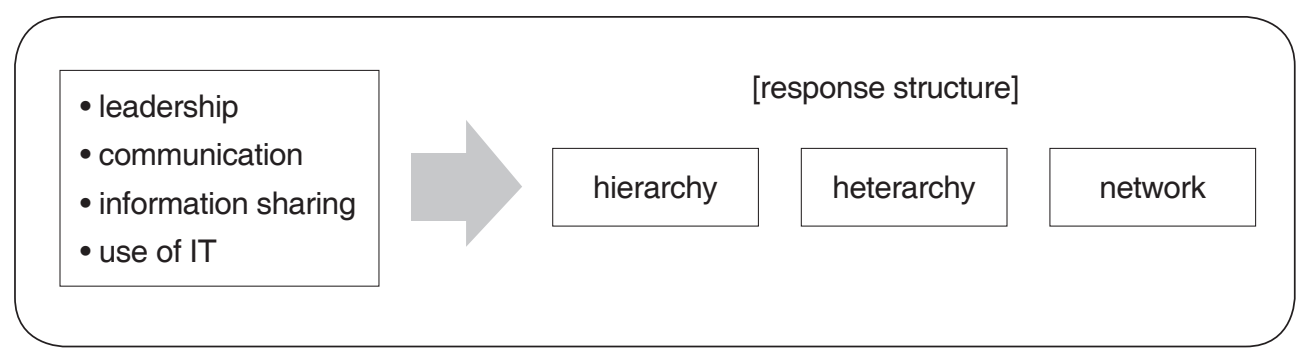

\section{Case Summary}

The MERS outbreak in South Korea began after a Korean man returned from a visit to Bahrain on May 20, 2015, with a fever and a cough and transmitted the virus through the hospitals as he wandered around trying to find a doctor. Although the Korean government claimed that the rate of infection was not high, the number of 
infected rose to over 100 people within one month. Even worse, the number of people who died grew, as did the number of tertiary and quaternary infections.

In spite of these developments, the central government remained close-lipped on the path of MERS transmission, and hospitals retained confidentiality, which contributed to the demand on the part of the public opinion and the local governments for information sharing. However, the Seoul mayor's quick briefing seven days later led the central government to make information related to the MERS path available and to make public the list of 24 hospitals where the infection had occurred (see table 1). The infectee numbers began to decrease following this announcement. Nonetheless, although the information was finally made available, the central government was berated for its late initial response. The joint mission of the World Health Organization and Korea concluded that the initial response to MERS was a failure because the Korean government delayed sharing information. In total, it took about 60 days before the MERS outbreak was finally contained (table 1).

Table 1. Chronology of Events for Combating MERS

\begin{tabular}{c|l|l}
\hline Date & \multicolumn{1}{|c|}{ Key events } & \multicolumn{1}{c}{ Key Organizations } \\
\hline 5.20 & first infectee reported in Korea & $\begin{array}{l}\text { Korean Center for Disease } \\
\text { Control and Prevention }\end{array}$ \\
\hline 5.21 & $\begin{array}{l}\text { MERS outbreak begins government issues a } \\
\text { statement about MERS disease readiness level: } \\
\text { blue } \rightarrow \text { yellow central antidisease headquarters } \\
\text { established }\end{array}$ & $\begin{array}{l}\text { Korean Center for Disease } \\
\text { Control and Prevention }\end{array}$ \\
\hline 5.28 & $\begin{array}{l}\text { central anti-MERS headquarters established } \\
5.29\end{array}$ & $\begin{array}{l}\text { Korean Center for Disease } \\
\text { Control and Prevention } \rightarrow \\
\text { Ministry of Health and } \\
\text { Welfare }\end{array}$ \\
\hline 5.30 & $\begin{array}{l}\text { Pyeong-taek St. Mary's Hospital partially shut } \\
\text { down }\end{array}$ & $\begin{array}{l}\text { Ministry of Health and } \\
\text { Welfare }\end{array}$ \\
\hline 6.1 & $\begin{array}{l}\text { Pyeong-taek St. Mary's } \\
\text { fospital, Ministry of Health } \\
\text { and Welfare }\end{array}$ \\
\hline quarantined
\end{tabular}




\begin{tabular}{|c|c|c|}
\hline 6.3 & $\begin{array}{l}\text { pan-government anti-MERS headquarters } \\
\text { established }\end{array}$ & $\begin{array}{l}\text { Ministry of Health and } \\
\text { Welfare } \rightarrow \text { Ministry of } \\
\text { Public Safety and Security }\end{array}$ \\
\hline 6.4 & $\begin{array}{l}35^{\text {th }} \text { infectee participates in a big symposium; } \\
\text { nighttime briefing by Seoul mayor }\end{array}$ & $\begin{array}{l}\text { Seoul City (local } \\
\text { government) }\end{array}$ \\
\hline 6.5 & disaster security text message sent & $\begin{array}{l}\text { Ministry of Public Safety } \\
\text { and Security }\end{array}$ \\
\hline 6.7 & $\begin{array}{l}\text { MERS path and list of patients in hospitals made } \\
\text { public }\end{array}$ & $\begin{array}{l}\text { Ministry of Public Safety } \\
\text { and Security, Ministry of } \\
\text { Health and Welfare }\end{array}$ \\
\hline 6.9 & World Health Organization visits Korea & $\begin{array}{l}\text { Ministry of Health and } \\
\text { Welfare, World Health } \\
\text { Organization }\end{array}$ \\
\hline 6.10 & MERS portal opened (www.mers.go.kr) & $\begin{array}{l}\text { Ministry of Health and } \\
\text { Welfare, citizens }\end{array}$ \\
\hline 6.11 & MERS hotline set up & $\begin{array}{l}\text { Ministry of Health and } \\
\text { Welfare, citizens }\end{array}$ \\
\hline 6.14 & Samsung Medical Center partially shut down & Samsung Medical Center \\
\hline 6.15 & 5 quaternary infections reported & $\begin{array}{l}\text { medical organizations, } \\
\text { Korean Hospital } \\
\text { Association, } \\
\text { Korean Medical } \\
\text { Association }\end{array}$ \\
\hline 6.16 & $154^{\text {th }}$ infectee reported in Daegu City & $\begin{array}{l}\text { Ministry of Health and } \\
\text { Welfare, Daegu City (local } \\
\text { government) }\end{array}$ \\
\hline 7.6 & $\begin{array}{l}\text { laws revised pertaining to the prevention and } \\
\text { management of infectious disease }\end{array}$ & $\begin{array}{l}\text { Ministry of Health and } \\
\text { Welfare }\end{array}$ \\
\hline 7.20 & $\begin{array}{l}\text { Samsung Medical Center's partial shutdown } \\
\text { lifted }\end{array}$ & $\begin{array}{l}\text { Ministry of Health and } \\
\text { Welfare, Samsung Medical } \\
\text { Center }\end{array}$ \\
\hline 7.21 & $186^{\text {th }}$ infectee cured; zero infectees remain & $\begin{array}{l}\text { Ministry of Health and } \\
\text { Welfare }\end{array}$ \\
\hline 7.28 & declared de facto MERS-free & $\begin{array}{l}\text { Ministry of Health and } \\
\text { Welfare }\end{array}$ \\
\hline
\end{tabular}




\section{DATAAND METHOD}

According to Yin (2013, p. 11-13), using a case study to examine contemporary events is preferable to other methods because cases studies help researchers to answer "how" and "why" questions. Therefore, this is the method I have adopted in order to answer the questions of how a governance structure emerges and why it is formed.

The research design was conducted as a "single case study" (Yin, 2013, p. 240) to examine the case of the MERS crisis. A single case study as opposed to a multiple case study is used when the research concerns a critical, common, unusual, revelatory or longitudinal issue. However, this study is also a "descriptive case study" whose purpose is to describe a phenomenon in its real-world context (Yin, 2013, p. 238).

In order to achieve a convergence of evidence, I utilized data triangulation (Yin, 2013, pp. 120-121), which helps to strengthen the construct validity of the case study. Multiple data sources were collected from various kinds of documentation, including central and local government press releases, government-published reports, public and private hospitals' published reports, newspapers, public health or medical-related nongovernmental organization reports, and secondary surveys and interviews. For newspapers, the specific data period selected was between May 20 and July 28, 2015, when the government declared a de facto end to MERS because new infections had not been found for more than three weeks, but also includes December 2015. The reason why I included newspaper stories from December is that although the main MERS crisis period was from May to July, the Korean government announced that the country was officially MERS-free on December 23, when the last infected person was cured, 218 days after the first MERS case appeared.

\section{CASE ANALYSIS}

I have divided the crisis into three periods: May 21-June 4, June 4-June 9, and June 9-July 28. Using the data and documents I collected, I explored who the key actors were in the MERS crisis, and with these criteria I identified which governance structure dominated in each period and what factors contributed to the formation of each structure. The figures representing response structures in each period are based on Cumming's socio-ecological systems (2016, p. 9). 


\section{Period 1 (Days 0-14): May 21 (Korean Government's Statement) - June 4 (Mayor of Seoul's Briefing)}

\section{Organization}

In the section dealing with period 1, I also divide the research period into two further subdivisions by the key organizations that led the response to MERS. Interestingly, as it turned out, two key organizations were observed in period 1 .

From May 21 to 28, the first week of the outbreak, the main organization leading the response in the central government was the Korean Center for Disease Prevention and Control. It raised its disease readiness level from blue (the lowest) to yellow (the second lowest). It then established a central antidisease headquarters, which the director of Korean Center for Disease Prevention and Control was placed in charge of (Ministry of Health and Welfare, 2016).

One week later, the central antidisease headquarters was expanded and reorganized as the central anti-MERS headquarters. The director of this organization became the vice minister of the Ministry of Health and Welfare, and then five days later, on June 2 , the minister assumed the role of director for two days. Thus, the main organizations involved in period 1 were the Korean Center for Disease Prevention and Control and the Ministry of Health and Welfare (Ministry of Health and Welfare, 2016).

\section{Leadership}

During the whole of period 1, the central government responded to the crisis by declining to share any command-and-control information concerning the MERS path with the public. Instead, it emphasized its authority and claimed that information about the disease would be shared only with hospitals, because the disease was being spread only in these institutions. In an interview on June 23, 2015, a staff member of Pyeongtaek St. Mary's Hospital said, "The Korean Center for Disease Control and Prevention asked us to hide the fact of the MERS outbreak to our patients in hospitals because it said the transmission rate was not that high, so if it was revealed, it could confuse patients" (S. I. Park, 2015). ${ }^{6}$

The imbalance of power in the leadership during period 1 negatively affected the

6. Actually, documenting a virus's path is not a duty of the government. However, when an outbreak occurs, most developed countries announce who is infected, where the infected have traveled to and from, and what communities and hospitals the infected are in. For example, the United States, France, the Netherlands, and Germany provided information about the MERS path. 
disaster management collaboration (Hardy and Philip, 1998). A few interest groups of medical personnel and hospitals such as the Samsung Medical Center, in which over half of MERS patients were infected during the outbreak, stood to benefit from the Ministry of Health and Welfare and the Korean Center of Disease Control and Prevention. The crisis decisions were made by small groups of political and administrative elites within the central government (Drennan, McConnell, \& Stark, 2014, p. 164) with these interest groups which contained the MERS. This allowed the government to preserve its vested interests. Consequently, a power imbalance was revealed in period 1 , and there was no specific leadership during the initial response to the MERS outbreak (Ministry of Health and Welfare, 2016).

\section{Communication and Information Sharing}

The media and the press requested that the Ministry of Health and Welfare make public the list of hospitals housing MERS patients; citizens faced a threat of infection and death and wanted information from the government. However, the government maintained its policy of not sharing information with the public (Choi, 2015). The central government's refusal to share information created an atmosphere amenable to the spread of rumors. Furthermore, the government shut down communication channels and announced that those who spread rumors would be punished.

\section{Use of IT}

People were scared after tertiary infections were confirmed. Rumors began to spread very quickly through various internet blogs and communities online. Online networks became a movement for citizens who distrusted the government to take matters into their own hands. After two people died of MERS, citizens launched a website with a map showing the proliferation of MERS, which was based on Google maps, and they collected information about MERS using an "open information system" that made it possible for everyone to report on and follow the progression of the infection (J. H. Lee, 2015; Yoon, 2015). A public response to the pandemic emerged, and shortly afterward, information started to be rapidly disseminated via other social network services (i.e. Facebook, Twitter).

While the central government did not share information with local governments, the public, or even the media, private agencies, including hospitals and medical associations, shared information via the mobile community (using the Naver Band app) (Kim, 2015). These agencies repeatedly called on the government to make information available after a dramatic rise in the spread of the virus in hospitals. The Korean Hos- 
pital Association planned to hold a press conference on June 5, but the government would not permit it to do so. This was confirmed on July 26 in an interview with $\mathrm{Mr}$ Song, the head of the emergency center at E-cheon hospital, who said: "We were planning to announce a list of hospitals at the press conference, but it was canceled. I think there was outside pressure. A staff member at the Ministry of Health and Welfare said there are more costs than benefits. I think the central government had no intention of making it public then" (S. W. Park, 2015).

\section{Response Structure: Hierarchy}

It can be concluded based on what I have described that hierarchy, understood as a chain of command based on authoritative control (Stephenson, 2008), was the dominant response structure in period 1 . The political interests of bureaucrats, who lacked leadership and who communicated either only vertically or not at all with other actors such as local governments, media, and citizens, undoubtedly accounts for why such a hierarchical structure prevailed. As shown in figure 2, the initial MERS response structure was a traditional hierarchical one in which the central government controlled the other organizations. Here, I have made a distinction between major hospitals where many people were infected with MERS and smaller medical establishments, as the former group is considered to be an interest group of the government in this case.

Figure 2. Hierarchical Structure (Period 1)

\section{Period 2 (Days 14-19): June 4 (Mayor's Briefing) - 9 (Establishment of MERS Control Tower)}

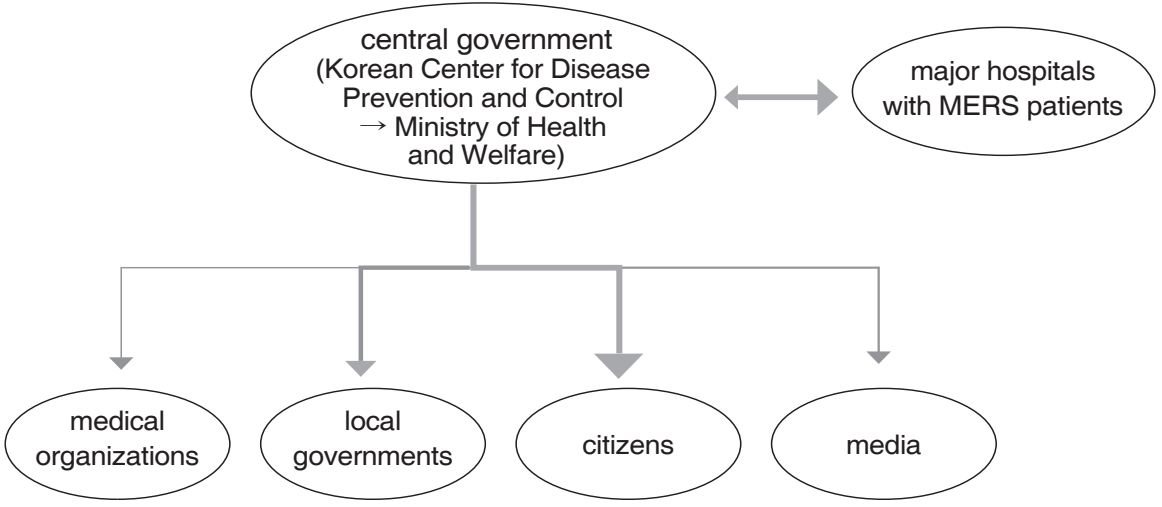

* The circles indicate nodes (organizations); arrows, interactions (relationship), size and thickness of arrows, power. 


\section{Organization}

The key organizations in period 2 turned out to be the central government, the local governments, and citizens. The most vital organization was a pangovernment antiMERS headquarters made up of 11 central and local government departments (Ministry of Health and Welfare, 2016), including the Ministry of Public Safety and Security, the Ministry of Health and Welfare, the Office for Government Policy Coordination, the Ministry of Foreign Affairs, the Ministry of Education, the Ministry of National Defense, the Ministry of Government Administration and Home Affairs, the Ministry of Culture, Sports, and Tourism, the Ministry of Agriculture, Food, and Rural Affairs, the Ministry of Oceans and Fisheries, and the National Police Agency along with local governments. This pangovernment organization, directed by the secretary of the Ministry of Public Safety and Security, was assembled to support the central anti-MERS headquarters (which was the key organization in the latter part of period 1).

\section{Leadership}

It was facilitative leadership that triggered the change in the governance structure during the 2015 Korean MERS epidemic. A facilitative leadership is a condition of collaborative governance (Ansell \& Gash, 2008). Wonsoon Park, mayor of Seoul, held a quick briefing out of the blue late at night on June 3, after being informed of the identity of the 35th MERS infectee and where he had been, at which he issued the following statement: "I suggest that for the citizens' safety, an overresponse [to MERS] is much better than a late response."

\section{Communication and Information Sharing}

Although Mayor Park was criticized for taking unilateral action and making speech without any discussion with the central government, his decision to disclose MERSrelated information to the general public prevented the disease from spreading further within the country. This approach also encouraged the central government to delegate its authority to the local government in Seoul to an extent, thus empowering it to take action. This was not whole but partial empowerment, giving it a modicum of autonomy to assume command and control in its boroughs - including Seoul, Gyeong-gi, Daejon, and Choongnam. For instance, when a case of MERS occurred at a hospital, the city was able to shut it down autonomously, as noted in an interview, on July 15 by a Mr. Kim a government official in the health planning department: "When a MERS-positive patient stayed in a hospital in Yang-cheon, one of the boroughs of Seoul City, on June 7. ... We took measures to set up a cohort isolation of the whole hospital building. That 
response was rapid" (Seoul City, 2015).

The central government also permitted the most important boroughs, such as Seoul, Gyeong-gi, Daejon, and Choongnam, to implement their own MERS-related policy and communicate directly with the branch of the Institute of Health Environment within their regions. However, a hierarchical relationship still obtained between the central government and local government insofar as the central government had more authority and power than its local counterpart. Hence, the abdication of absolute control by the central government produced a governance structure that featured heterarchical leadership. The mayor of Seoul's briefing instigated change, resulting in the central government's opening of communication channels, one manifestation of which was its sending disaster text messages from the Ministry of Public Safety and Security to the public on June 5 .

\section{Use of IT}

The MERS maps created by netizens during the first period encouraged civilians to take further action and demand that the government provide information pertaining to the MERS path as well as lists of hospitals to the public. New information technologies were used, in ways similar to the way Landesman (2012) has suggested IT should be used in disaster planning, to change the governance structure, leading to flattened hierarchies. Finally, on June 7, the central government made public 24 hospitals with MERS patients and their paths.

In period 2, therefore, information flowed much quicker than it did in period 1 , giving actors more opportunities to interact, which is typical in heterarchies.

\section{Response Structure: Heterarchy}

The Seoul mayor's information sharing challenged the central government hierarchy and introduced heterarchy. However, the heterarchical structure was not very flat, as several local governments in the structure were organized hierarchically. Nevertheless, they networked together with each other as local governments. Even though the network structure that emerged does not fit Stephenson's (2014) model of heterarchy perfectly, it comes close, and thus I would conclude that heterarchy describes this period's response structure. 
Figure 3. Heterarchical Response Structure

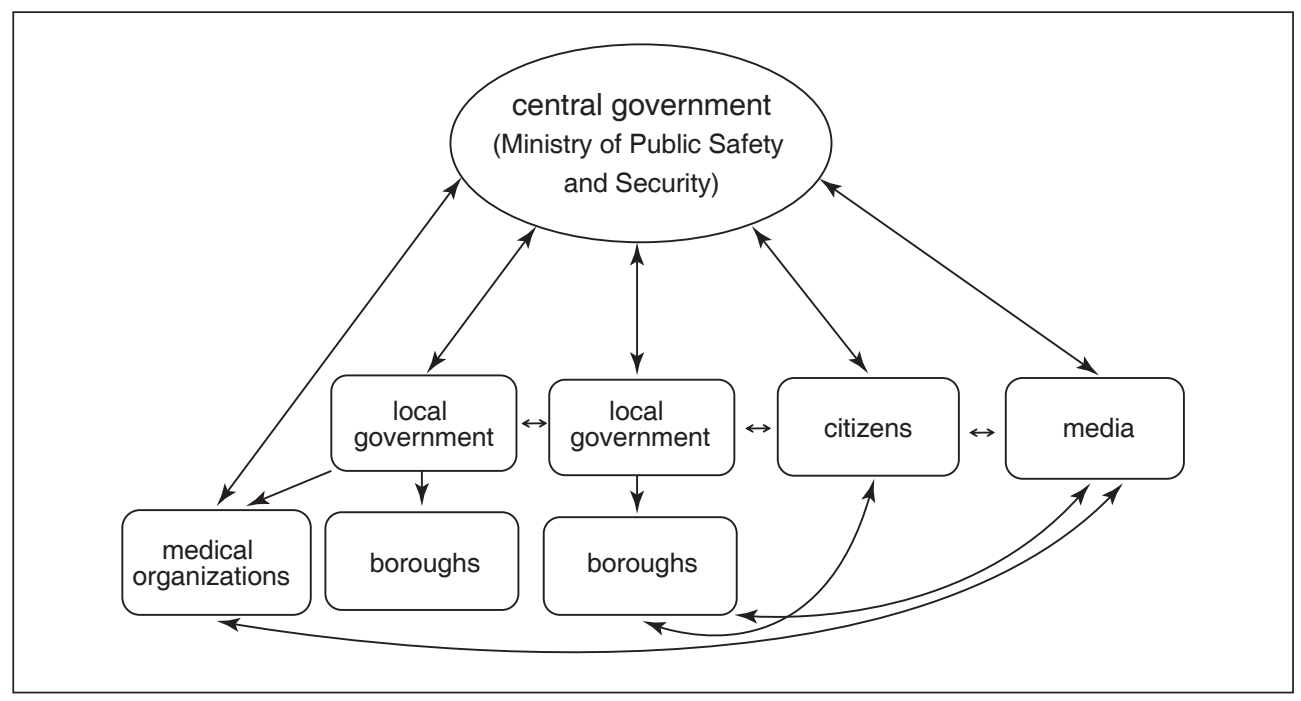

Period 3 (Days 14-50): June 9 - July 28

\section{Organization}

The central anti-MERS headquarters led by the Ministry of Health and Welfare, the World Health Organization, local government, citizens, and hospitals were the key organizations that participated in the MERS response structure in period 3.

In this period, the pangovernment anti-MERS headquarters, led by the Ministry of Public Safety and Security in period 2, was replaced with the central anti-MERS headquarters, led by the Ministry of Health and Welfare. The Ministry of Health and Welfare of Korea also envisaged this period as an "active response stage" (Ministry of Health and Welfare, 2016).

\section{Leadership}

A team from the World Health Organization visited Korea on June 9, and the Korean government conducted a joint mission with it for five days. ${ }^{7}$ The World Health

7. This joint mission consisted of World Health Organization members and individuals from 16 domestic and international professions. They had discussions, visited MERS inpatientand isolation hospitals, and analyzed characteristics of the MERS-Corona virus in collaboration with the Korean Centre for Disease Prevention and Control. See http://www. wpro.who.int/mediacentre/releases/2015/201506010/en/. 
organization advised the central government to take a more active role in responding to the MERS crisis, and the government did so from that point forward. By designating MERS hospitals, the government was able to provide medical agencies and infectious disease management agencies with the necessary resources, such as movable sound pressure equipment and sound pressure tents. A dramatic increase in the number of patients was the main reason for the lack of negative pressure isolation rooms in the Seoul, Gyeonggi, Daejeon, and Chungcheong areas. The Korean National Medical Center provided personal protective and therapy equipment, and the central antiMERS headquarters provided relational equipment to the designated hospitals (Ministry of Health and Welfare, 2016). Even though there was still criticism over the fact that there was no MERS response control tower, the central anti-MERS headquarters served as a de facto control tower, which helped transform the initial hierarchical response structure into a more collaborative one.

\section{Communication and Information Sharing}

The central government made an effort to communicate directly with the citizens by securing several communication channels. First, the government established a MERS portal website that explained what MERS-coV is, what its symptoms are, what to do in the event one suspected one had contracted the virus, and how to report a suspected infection. This communication channel provided information to citizens and it enabled them to gain feedback from each other.

\section{Use of IT}

People communicated via social network services such as Facebook and Twitter. Moreover, on June 11, a MERS hotline was established, and if people suspected they had MERS they could call it for free. The change in the way the government communicated with the public was rapid and radical.

The government also let private-sector organizations like the Korean Medical Association, the Korean Hospital Association, and other medical organizations participate in these networks, Furthermore, the government accepted applications from hospitals across the nation and designated 161 hospitals as patient safety hospitals. These hospitals separated general patients and respiratory patients in order to slow down the spread of MERS.

\section{Response Structure: Network (Lead Organization Network)}

When a disaster occurs, networks become highly centralized, and a lead organization may be needed to govern other members. In period 3, the network was headed up 
by a lead organization. A network is defined as "three or more nodes arrayed in a triad" (Stephenson, 2008). Several nodes like the central government, local governments, civil society, medical organizations, and so forth participated in the network.

The central anti-MERS headquarters, led by the Ministry of Health and Welfare, which is a central government body, can be described as the lead organization in this period (Kenis and Provan, 2009). This organization also included a task force consisting of private sector professionals, as well as immediate response and implementation teams. Local governments, which have a strong relationship with the central government, likewise had immediate response and implementation teams that could rapidly respond to new MERS infections. The Ministry of Health and Welfare also worked with medical organizations such as the Korean Medical Association and the Korean Hospital Association, which participated in the network for not only because it served their personal interests but also because they trusted the ministry. The network governance structure dominating this period is represented in figure 4.

Figure 4. Network Governance Structure

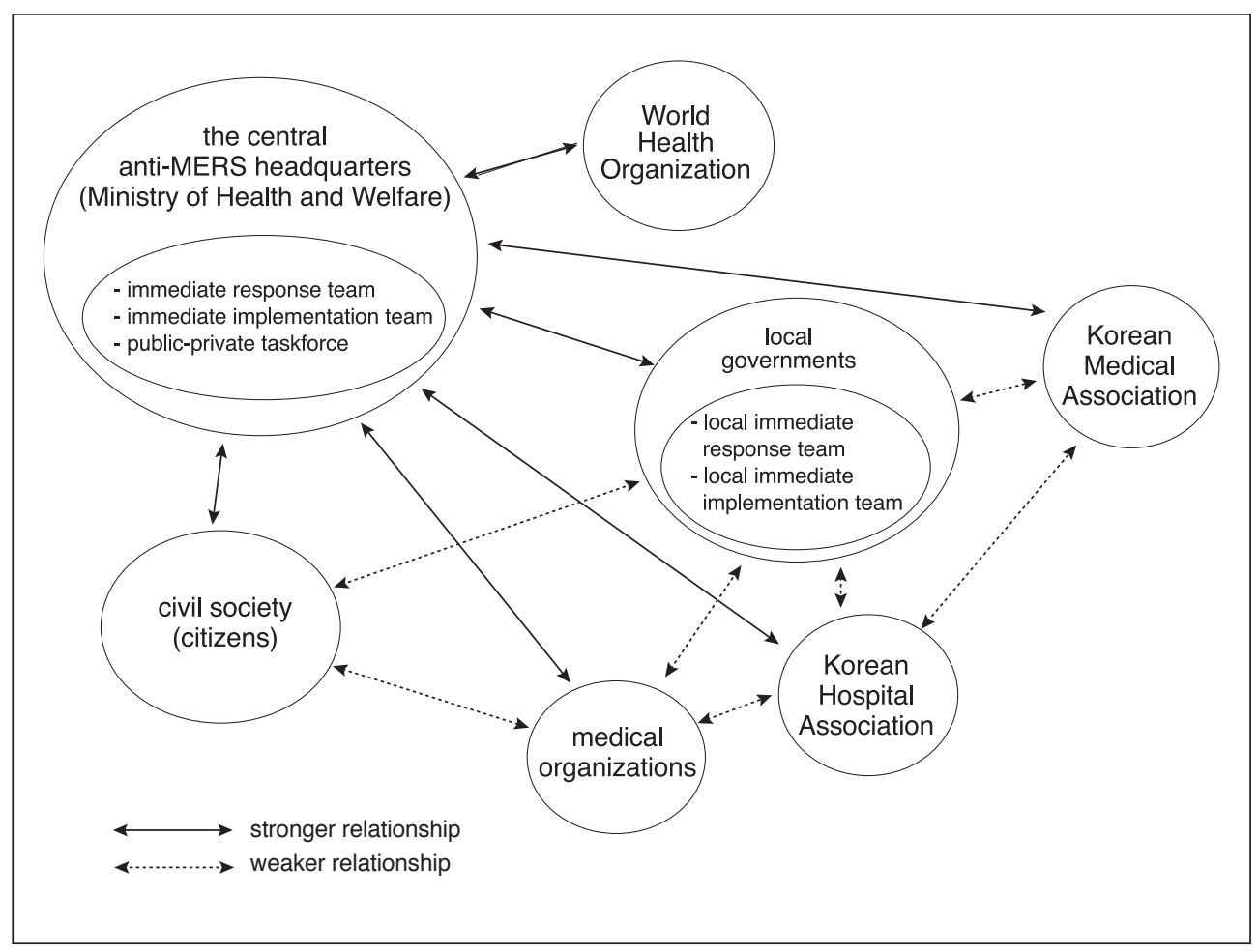




\section{IMPLICATIONS}

The government's initial delayed response to MERS and its failure to communicate with the public spread anxiety and decreased citizens' trust in it, which ultimately compelled the government to develop policies for improving infectious disease prevention. First of all, the central government enacted and revised the Infectious Disease Control and Prevention Act, which came into law in January 2016..$^{8}$ In addition, the government added an emergency response center to the Korean Center for Disease Prevention and Control, which includes a department that manages crisis communication.

After the declaration of that the country was MERS-free, local governments began to collaborate more effectively with the central government and hospitals within their province, building community capacity by offering citizens response training and training in operating emergency response systems. Before the MERS outbreak, the Gyeonggi Infectious Disease Control Center had already established a network governance structure for infectious disease management, collaborating with the Korean Centre for Disease Prevention and Control, the Gyeonggi provincial government (a local government), and the Boondang Seoul National University hospital in developing strategies for preventing and responding to public health crises and securing the community's response capabilities in advance..$^{9}$ Likewise, other local governments, such as Jeolla, Jeju, Pusan, and Seoul established infectious disease control centers in the spring and summer of 2016, and a center should be opened in Daegu in 2017. Moreover, Incheon, Gyeonggi, and Seoul reached a joint agreement for reinforcing infectious disease response capacity in September 2016 (Mok, 2015).

Recovery plans and preparedness are also now expected from medical organizations. Private hospitals are preparing to prevent infectious disease in many ways. For example, one year after the MERS outbreak, in May 2016, Myeong-gi hospital became one of the first private hospitals to establish an infectious disease and emergency response research center in Korea. Additionally, the Samsung Medical Center, where over half of the MERS infections occurred, has separated the inpatient clinic

8. The newly inserted part of article 4, which outlines duties of state and local governments, reads as follows: "(3) State and local governments (including superintendents of education) shall share information on diseases and information pertaining to outbreaks and proliferation thereof and mutually cooperate in order to efficiently eradicate them and prevent the spread thereof. (4) State and local governments shall share the relevant information with medical institutions and medical personnel associations under the Medical Service Act in order to monitor and prevent the outbreak of infectious diseases."

9. See http://gidcc.or.kr/kr/main/main.html. 
building from the general clinic center and emergency center.

The period from July 28 to the present can be categorized as period 4, in which organizations have been focusing on recovering from MERS and preventing the next epidemic and in which a network governance structure has persisted.

\section{CONCLUDING REMARKS}

The present study has focused on the Korean MERS epidemic and analyzed how governance structures were set up and responded to it. Compared to other countries' responses, which featured both hierarchical and network structures, the Korean MERS response structure evolved over time. In the first period, hierarchy dominated; in the second period, heterarchy prevailed; and in the last period, a network governance structure emerged. Furthermore, this study found that the quality of the leadership and the level of communication, information sharing, and use of information technology affected the formation of the response structures.

The evaluation of the Korean government's response to MERS has been conflicted. Various media outlets and studies have pointed out that the initial stage of the response was a failure due to a lack of crisis communication and information sharing (Choe, 2015), whereas the World Health Organization suggested its response was good (Kim, 2015). Dr. Keiji Fukuda, World Health Organization assistant director-general, said that overall the Korean government responded quite well considering that any country would have a hard time responding to a new disease.

Lessons learned from the initial response failure to MERS are that the Korean government should develop more network-type approaches to managing disasters, such as a crisis communication channel and information-sharing systems. As Dr. Fukuda warned (McIntosh, 2015), as epidemics are the global challenge of modern times, we have to consider this outbreak a "wake-up call" and be on the alert for the next one.

This study has its limitations. It is hard to generalize from a single case study and relate the findings to other national crises. Therefore, future studies ought to carry out multiple case study analyses. Similarly, generalization is difficult because this case was limited to Korea and to one epidemic. Research on other countries' responses to crises and comparative studies are needed. Moreover, the study mostly depended on documents and secondary sources because not enough primary sources were available.

Nonetheless, this study will provide a basic resource for public health disaster response research and will contribute to shaping the government's response in to similar future pandemics. 


\section{REFERENCES}

Acheson, D. 1988. Public health in England. London: Department of Health.

Agranoff, R., \& McGuire, M. 1998. The intergovernmental context of local economic development. State and Local Government Review, 30(3): 150-164.

Alexander, D. 2007. Disaster management: From theory to implementation. Journal of Seismology and Earthquake Engineering, 9(1-2): 49.

Ansell, C., Boin, A., \&Keller, A. 2010. Managing transboundary crises: Identifying the building blocks of an effective response system. Journal of Contingencies and Crisis Management, 18(4): 195-207.

Ansell, C., \& Gash, A. 2008. Collaborative governance in theory and practice. Journal of public Administration Research and Theory, 18(4): 543-571.

Ansell, C., \& Keller, A. 2014. Adapting the incident command model for knowledgebased crises: The case of the centers for disease control and prevention. Washington, DC: IBM Center for the Business of Government.

Bailetti, A. J., Callahan, J. R., \&DiPietro, P. 1994. A coordination structure approach to the management of projects. IEEE Transactions on Engineering Management, 41(4): 394-403.

Bardach, E. 2015. Networks, Hierarchies, and Hybrids. International Public Management Journal, original article, 1-26.

Baum, A., Fleming, R., \& Davidson, L. M. 1983. Natural disaster and technological catastrophe. Environment and Behavior, 15(3): 333-354.

Benoit, W. L. 1995. Accounts, excuses, and apologies: A theory of image restoration strategies. Barcelona: Marcombo.

Bryson, J. M., Crosby, B. C., \& Stone, M. M. (2006). The design and implementation of cross-sector collaborations: Propositions from the literature. Public Administration Review, 66(s1): 44-55.

Berry, F. S., Brower, R. S., Choi, S. O., Goa, W. X., Jang, H., Kwon, M., \&Word, J. 2004. Three traditions of network research: What the public management research agenda can learn from other research communities. Public Administration Review, 64(5): 539-552.

Chess, C., Hance, B. J., \& Sandman, P. M. 1989. Planning dialogue with communities: $A$ risk communication workbook. Environmental Communication Research Program.

Choi H., 2015. The Ministry of Health and Welfare's lack of communication about MERS. Kyunghyang Ibo. Retrieved on April 2, 2017, from http://news.khan. co.kr/kh_news/khan_art_view.html?artid=201506022205515\&code=940601.

Choe, Sang-Hun. 2015. Experts fault South Korean response to MERS outbreak. New York Times, June 13. Retrieved from www.nytimes.com/2015/06/14/world/asia/ 
experts-fault-south-korean-response-to-mers-outbreak.html?_r=0

Churchman, C. W. 1967. Guest editorial: Wicked problems. Management Science, 14(4): B141-142.

Comfort, L. K. 1988. Designing policy for action: The emergency management system. Managing Disaster. In L K. Comfort (ed.), Managing Disaster: Strategies and Policy Perspectives (pp. 3-21). Durham, NC: Duke University Press.

Comfort, L. K. 2007. Crisis management in hindsight: Cognition, communication, coordination, and control. Public Administration Review, 67(s1): 189-197.

Coombs, W. T. 1995. Choosing the right words: The development of guidelines for the selection of the "appropriate" crisis-response strategies. Management Communication Quarterly, 8(4): 447-476.

Coombs, W. T. 2009. Conceptualizing crisis communication. In R. L. Heath, \& D. H. O’Hair (eds.), Handbook of Risk and Crisis Communication (pp. 99-118). London: Routledge.

Coombs, W. T. 2014. Ongoing crisis communication: Planning, managing, and responding. Thousand Oaks, CA: Sage Publications.

Covello, V. T. 1992. Risk communication: An emerging area of health communication research. Annals of the International Communication Association, 15(1): 359-373.

Cumming, G. S. 2016. Heterarchies: Reconciling networks and hierarchies. Trends in ecology and evolution, 31(8): 622-632.

Denis, J., Ferlie, E., \& Van Gestel, N. 2015. Understanding hybridity in public organizations. Public Administration, 93(2): 273-289.

Drennan, L. T., McConnell, A., \& Stark, A. 2014. Risk and crisis management in the public sector. New York: Routledge.

Dynes, R. R. 1970. Organized behavior in disaster. Lexington, MA: Heath Lexington Books.

European Centre for Disease Prevention and Control [EDCD]. 2016. Epidemiological update: Outbreaks of Zika virus and complications potentially linked to the Zika virus. Retrieved on March 30, 2017, from http://ecdc.europa.eu/en/press/ news/_layouts/forms/News_DispForm.aspx?ID=1488\&List=8db7286c-fe2d476c-9133-18ff4cb1b568\&.

Ferlie, E., \& Pettigrew, A. 1996. Managing through networks: Some issues and implications for the NHS. British Journal of Management, 7(s1): S81-S99.

Ferlie, E., McGivern, G., \& Bennett, C. 2013. Making wicked problems governable? the case of managed networks in health care. Oxford: Oxford University Press.

Forrer, J., Kee, J. J., \& Boyer, E. 2014. Governing cross-sector collaboration. New York: Wiley. 
Fountain, J. E. 2004. Building the virtual state: Information technology and institutional change Washington, DC: Brookings Institution Press.

Fung, I. C., Tse, Z. T. H., Chan, B. S. B., \&Fu, K. 2015. Middle East respiratory syndrome in the republic of Korea: Transparency and communication are key. Western Pacific Surveillance and Response Journal 6(3): 1.

Geser, H. 1992. Towards an interaction theory of organizational actors. Organization Studies, 13(3), 429-451.

Goldsmith, S., \& Eggers, W. D. 2005. Governing by network: The new shape of the public sector. Washington, DC: Brookings Institution Press.

Gostin, L. O. 2001. Public health, ethics, and human rights: A tribute to the late Jonathan Mann. Journal of Law, Medicine, and ethics, 29(2): 121-130.

Grabher, G. 1993. The embedded firm. London: Routledge.

Haddow, G., Bullock, J., \& Coppola, D. P. 2013. Introduction to emergency management. Oxford, UK: Butterworth-Heinemann.

Hardy, C., \& Phillips, N. 1998. Strategies of engagement: Lessons from the critical examination of collaboration and conflict in an interorganizational domain. Organization Science, 9(2): 217-230.

Hermansson, H. M. 2016. Disaster management collaboration in Turkey: Assessing progress and challenges of hybrid network governance. Public Administration, 94(2): 333-349.

Hodgkinson, P. E., \&Stewart, M. 1991. Coping with catastrophe. London: Routledge.

James, E. H., \&Wooten, L. P. 2010. Leading under pressure: From surviving to thriving before, during, and after a crisis. London: Routledge.

Kapucu, N. 2005. Interorganizational coordination in dynamic context: Networks in emergency response management. Connections, 26(2): 33-48.

Kapucu, N. 2006. Interagency communication networks during emergencies boundary spanners in multiagency coordination. American Review of Public Administration, 36(2): 207- 225.

Kapucu, N., Arslan, T., \& Collins, M. L. 2010. Examining intergovernmental and interorganizational response to catastrophic disasters: Toward a network-centered approach. Administration and Society. 42(2): 222-247.

Kasperson, R. E., \& Pijawka, K. D. 1985. Societal response to hazards and major hazard events: Comparing natural and technological hazards. Public Administration Review, 45, special issue, 7-18.

Kenis, P., \& Provan, K. G. 2009. Towards an exogenous theory of public network performance. Public Administration, 87(3): 440-456.

Kim, E. S., Chung, J. B., \& Ahn, H. K. 2009. A study of the policy paradigms for national disaster and safety management. Seoul: Korea Institute of Public 
Administration.

Kim, 2015. WHO, "Korea responded well to MERS," but media rebuts. Ohmynews, June 13. Retrieved on March 29, 2017, from www.ohmynews.com/NWS_Web/ View/at_pg.aspx?CNTN_CD=A0002118162.

Koppenjan, J. F. M., \& Klijn, E. 2004. Managing uncertainties in networks: A network approach to problem solving and decision making. New York: Psychology Press.

Landesman, L. Y. 2012. Public health management of disasters: The practice guide (3rd ed.). Washington, DC: American Public Health Association.

Lee, K. S. 2015. Health medical policy: A new paradigm. Seoul: Gyechuk.

Lee, J. Y., Lee, J. Y., Choi, J. S., \& Chung, J. B. 2014. Disaster management. Seoul: Daeyoung .

Lee, J. H. 2015. Netizens launch MERS tracking map. Korea Times, June 4. Retrieved on March 30, 2017, from www.koreatimes.co.kr/www/news/nation/2015/06/ 116 180192.html.

Leidner, D. E., Pan, G., \&Pan, S. L. 2009. The role of IT in crisis response: Lessons from the SARS and Asian Tsunami disasters. The Journal of Strategic Information Systems, 18(2): 80-99.

Levinson, J., \& Granot, H. 2002. Transportation disaster response handbook. Cambridge, MA: Academic Press.

Lundgren, R. E., \& McMakin, A. H. 2013. Risk communication: A handbook for communicating environmental, safety, and health risks. New York: Wiley.

Mars, D. 2013. Heterarchy: An interorganizational approach to securing the United States against a pandemic threat. Policy Perspectives, 20: 100-117.

McIntosh, James. 2015. Assessing the South Korea MERS outbreak: could it happen elsewhere? Medical News Today, July 30. Retrieved on March 30, 2017, from www.medicalnewstoday.com/articles/297535.php.

McLoughlin, D. 1985. A framework for integrated emergency management. Public Administration Review, 45, special issue: 165-172.

Ministry of Health and Welfare. 2016. MERS white paper.

Mok. 2015. Incheon, Gyeonggi, and Seoul reach a joint-agreement for reinforcement of infectious disease response capacity. Kyeong-in Ibo, September 13. Retrieved on April 1, 2017, from www.giib.co.kr/main/view.php?key=20160913010004261.

Moynihan, D. P. 2008a. Combining structural forms in the search for policy tools: Incident command systems in US crisis management. Governance, 21(2): 205229.

Moynihan, D. P. 2008b. Learning under uncertainty: Networks in crisis management. Public Administration Review, 68(2): 350-365. 
Noji, E. K. 1996. The public health consequences of disasters. Oxford: Oxford University Press.

Nolte, I. M., \& Boenigk, S. 2011. Public-nonprofit partnership performance in a disaster context: The case of Haiti. Public Administration, 89(4): 1385-1402.

O’Toole, L. J., Jr. 1997. Treating networks seriously: Practical and research-based agendas in public administration. Public Administration Review, 57(1): 45-52.

O’Toole, L. J., \& Meier, K. J. 2004. Public management in intergovernmental networks: Matching structural networks and managerial networking. Journal of Public Administration Research and Theory, 14(4): 469-494.

Park, S. I. 2015. Korea, exposed to MERS. PD notebook. Seoul: MBC Broadcasting.

Park, S.W. 2015. Confessions about MERS. SBS special. Seoul: SBS Broadcasting.

Petak, W. J. 1985. Emergency management: A challenge for public administration. Public Administration Review, 45, special issue: 3-7.

Powell, W. 2003. Neither market nor hierarchy. In M.J. Handel (ed.), The Sociology of Organizations: Classic, Contemporary, and Critical readings. 315: 104-117. CA: Sage.

Preston, T. 2008. Weathering the politics of responsibility and blame: the Bush administration and its response to Hurricane Katrina. In A. Boin, A. McConnell and P.'t Hart (eds.), Governing after Crisis: The Politics of Investigation, Accountability and Learning (pp. 33-61). Cambridge University Press, Cambridge.

Quarantelli, E. L. 1993. Technological and natural disasters and ecological problems: Similarities and differences in planning for and managing them. Preliminary papers 192. Disaster Research Center, Newark, DE.

Rebmann, T. 2009. Infectious disease disasters: Bioterrorism, emerging infections, and pandemics. 3rd ed. Washington, DC: Association for Professionals in Infection Control and Epidemiology.

Reynolds, B., \& Seeger, M. W. 2005. Crisis and emergency risk communication as an integrative model. Journal of Health Communication, 10(1): 43-55.

Rhodes, R. A. 2000. Governance and public administration: Debating governance: authority, steering and democracy. Oxford: Oxford University Press.

Rittel, H.W., \& Weber, M.M. 1973. Dilemmas in general theory planning. Policy Sciences, 4(2): 155-169.

Rosenthal, U., Boin, R., \& Comfort, L. 2001. The changing world of crisis and crisis management. In U. Rosenthal, R. Boin, \& L. K. Comfort (eds.), Managing Crises: Threats, Dilemmas, Opportunities (pp. 5-27). Springfield, IL: Charles Thomas.

Schwartz, J. 2012. Compensating for the authoritarian advantage in crisis response: a comparative case study of SARS pandemic responses in China and Taiwan. 
Journal of Chinese Political Science, 17(3): 313-331.

Seeger, M. W., Reynolds, B., \& Sellnow, T. L. 2008. Crisis and emergency risk communication in health contexts: Applying the CDC model to pandemic influenza. In R. L. Heath, \& D. H. O'Hair (eds.), Handbook of Risk and Crisis Communication (pp. 493-506). London: Routledge.

Seoul City. 2015. MERS white paper.

Skelcher, C. 2012. What do we mean when we talk about 'hybrids' and 'hybridity' in public management and governance? Working Paper, Institute of Local Government Studies, Birmingham: University of Birmingham.

Skelcher, C., \& Smith, S. R. 2015. Theorizing hybridity: Institutional logics, complex organizations, and actor identities: The case of nonprofits. Public Administration, 93(2): 433-448.

Stephenson, K. 2008. Rethinking governance: Conceptualizing networks and their implications for new mechanisms of governance based on reciprocity. In T. Williamson. (ed.), The Handbook of Knowledge- Based Policing: Current Conceptions and Future Directions (pp. 323-340). New York: Wiley.

Stephenson, K. 2009. Neither hierarchy nor network: An argument for heterarchy. People and Strategy, 32(1): 4-13.

Stephenson, K. 2014. Essay: Hierarchy and heterarchy. Dossier Ecosystem voor ondernemen, 99(4698S): 54-59.

Thompson, G. 1991. Markets, hierarchies and networks: The coordination of social life. Thousand Oaks, CA: Sage.

Walaski, P. F. 2011. Risk and crisis communications: Methods and messages. New York: Wiley.

Waugh, W. L., Jr. 1994. Regionalizing emergency management: Counties as state and local government. Public Administration Review, 54(3): 253-258.

Waugh, W. L., Jr., \& Streib, G. 2006. Collaboration and leadership for effective emergency management. Public Administration Review, 66(s1): 131-140.

Wolfe, N. 2011. The viral storm: The dawn of a new pandemic age. New York: Macmillan.

Yin, R. K. 2013. Case study research: Design and methods. Thousand Oaks, CA: Sage.

Yoon, MS. 2015, June 4. Citizens take initiative in MERS fight. Korea Herald. Retrieved on March 30, 2017, from http://khnews.kheraldm.com/view.php?ud= 20150604001140\&md=20150605003116_BL.

World Health Organization. 2015. WHO publishes list of top emerging diseases likely to cause major epidemics. December 11. Retrieved on March 29, 2017, from www. who.int/medicines/ebola-treatment/WHO-list-of-top-emerging-diseases/en. 